\title{
Telaah Teoretis dan Yuridis Tukar Menukar Barang Milik Daerah dengan Swasta
}

\author{
Umbu Rauta, Titon Slamet Kurnia dan Arie Siswanto \\ Fakultas Hukum Universitas Kristen Satya Wacana \\ Jln. Diponegoro 52-60, Salatiga, Jawa Tengah, 50711 \\ umburauta@yahoo.com; titonslamet@gmail.com; ariesiswanto@yahoo.com
}

\begin{abstract}
This studybrought up the problems, first, the theoretical foundation of the exchange of regional owned property (BMD) between local government and private parties. Second, the laws and regulations governing the exchange activities of BMD. Third, basic considerations in relation to the exchange of BMD. The type of the research was normative research. The results concluded that, first, theoretically, the government (local government) can do contractualization of government affairs because this has become a practice (habit) in the government. The contractualisation includes exchange agreements with non-governmental parties that involve assets (land) that are under government control (BMD). Second, juridically, the regulational basis for the exchange agreement serving as the basis for the right to transfer the assets (land) under government control (BMD) can be found in the legislation. In doing such actions, terms and conditions of legislation shall apply as the basis of the validity of the actions which includes the aspects of authority, substance and procedure. Third, another thing that determines the feasibility of government action in exchanging BMD (in the form of land) is the aspect of benefit (doelmatigheid).
\end{abstract}

Keywords: Government contract; exchange; regional property

\begin{abstract}
Abstrak
Penelitian ini merupakan telaah teoretis dan yuridis terhadap perjanjian tukar menukar barang milik daerah (BMD), terutama tanah, antara pemerintah daerah dengan pihak swasta (non-pemerintah). Permasalahan yang akan dibahas meliputi dasar teoretis, peraturan perundang-undangan yang berlaku serta pertimbangan kemanfaatan yang berkaitan dengan tukar menukar BMD. Sebagai penelitian hukum maka pendekatan yang digunakan adalah pendekatan konseptual dan perundang-undangan. Berdasarkan hasil telaah ditemukan bahwa kontraktualisasi urusan pemerintahan sudah menjadi praktik lazim, termasuk perjanjian tukar menukar yang melibatkan BMD (tanah) yang berada di bawah penguasaan pemerintah daerah. Perjanjian tersebut dapat ditemukan pengaturannya dalam peraturan perundang-undangan sehingga memberikan sinyal bahwa tindakan tersebut diperbolehkan. Selain kesesuaian dengan peraturan perundang-undangan, perjanjian juga harus mempertimbangkan aspek kemanfaatan (doelmatigheid).
\end{abstract}

Kata-kata Kunci: Kontrak pemerintah; tukar menukar; BMD 


\section{Pendahuluan}

Tugas utama Pemerintah Daerah pada era otonomi daerah yaitu mewujudkan kesejahteraan masyarakat. Upaya ini ditempuh dengan menyelenggarakan pembangunan dan pemberdayaan masyarakat dari berbagai segi atau dimensi. Dalam praktik, aktivitas penyelenggaraan pembangunan tidak saja menjadi domain pihak pemerintah (publik), tetapi juga melibatkan pihak nonpemerintah (swasta).

Peran yang dilakukan pihak swasta dapat berupa keikutsertaan menyelenggarakan sejumlah urusan yang merupakan kegiatan pemerintah daerah (dalam wujud pengadaan barang dan jasa), maupun kegiatan yang benar-benar merupakan inisiasi murni dalam wujud menjalankan kegiatan usaha dalam bidang pertanian, peternakan, perdagangan, industri, dan lain sebagainya. Dalam menjalankan kegiatan usaha tersebut, acapkali pihak swasta diperhadapkan pada sejumlah kendala, salah satunya ketersediaan lahan yang strategis untuk mendukung usahanya. Sementara pada sisi yang lain, pemerintah daerah memiliki sejumlah lahan strategis yang tidak dapat diusahakan karena minimnya daya dukung dana. ${ }^{1}$ Dalam situasi demikian, baik atas inisiatif pihak swasta maupun inisiatif pemerintah daerah dilakukan upaya pengalihan barang milik daerah (selanjutnya disingkat BMD) atau biasanya dikenal dengan istilah tukar menukar tanah (ruilslag).

Tulisan ini hendak menguraikan aspek-aspek teoretis dan yuridis dalam kegiatan peralihan (baca: tukar menukar) BMD (khususnya berupa tanah) yang dilakukan oleh pihak Pemerintah Daerah dengan pihak swasta. Isu ini sangat penting karena pergeseran pengaturan terkait pengelolaan BMD dan juga karena kebutuhan untuk memberi kerangka hukum dan panduan bagi daerah-daerah di Indonesia dalam melakukan aktivitas tukar menukar BMD (khususnya tanah) dengan pihak swasta.

\section{Rumusan Masalah}

Tulisan ini difokuskan untuk menjawab beberapa pertanyaan sebagai berikut. Pertama, apakah landasan teoretis yang memayungi tukar menukar BMD antara

1 Urip Santoso, "Perjanjian Bangun Guna Serah antara Pemerintah Kabupaten/Kota dan Perseroan Terbatas", Mimbar Hukum, Volume 24, Nomor 1, 2014, hlm. 29. 
pemerintah daerah dengan pihak swasta? Kedua, apakah kegiatan tukar menukar tersebut telah dipayungi oleh ketentuan peraturan perundang-undangan? Ketiga, apakah keterpenuhan ketentuan peraturan perundang-undangan sudah memadai sebagai dasar untuk melakukan tukar menukar tersebut?

\section{Tujuan Penelitian}

Secara umum, sesuai dengan rumusan masalah di atas, tulisan ini bertujuan untuk memperoleh pemahaman yang utuh baik secara teoretis maupun yuridis kegiatan tukar menukar BMD antara pemerintah daerah dengan pihak swasta. Untuk itu, sistematika tulisan ini sebagai penjabaran tujuan tersebut adalah sebagai berikut. Pertama, akan dikemukakan kontrak pemerintah sebagai dasar teoretis umum dalam memahami tentang kegiatan tukar menukar antara pemerintah daerah dengan pihak swasta. Kedua, akan dijabarkan landasan peraturan perundang-undangan yang berkaitan dengan kontrak atau perjanjian tukar menukar BMD antara pemerintah daerah dengan pihak swasta. Ketiga, pertimbangan doelmatigheid (kemanfaatan) sebagai alasan yang dapat memperkuat keputusan untuk melakukan perjanjian tukar menukar (selain aspek keterpenuhan ketentuan peraturan perundang-undangan).

\section{Metode Penelitian}

Penelitian ini adalah penelitian hukum (legal research) yang hendak mengklarifikasi perspektif teoretis, landasan yuridis dan pentingnya aspek doelmatigheid dalam kaitan dengan tukar menukar barang milik daerah, terutama tanah. Terkait dengan itu pendekatan yang digunakan dalam penelitian adalah pendekatan konseptual (conceptual approach) dan pendekatan perundangundangan (statute approach). Sesuai dengan pendekatan yang digunakan maka bahan-bahan hukum yang digunakan adalah: (1) literatur di bidang Hukum Administrasi dan Perdata (bahan hukum sekunder); (2) peraturan perundangundangan terkait (bahan hukum primer). Bahan-bahan hukum penelitian ini diperoleh dengan cara penelitian pustaka (library-based research). Pembahasan atas rumusan masalah penelitian ini bertumpu pada analisis bahan-bahan hukum penelitian yang dilakukan dengan jalan pemaparan (deskripsi) secara katagoris atau topikal dan dengan teknik interpretasi. 


\section{Hasil Penelitian dan Pembahasan}

\section{Tukar Menukar dalam Perspektif Kontrak Pemerintah}

Fungsi atau urusan pemerintahan yang ditangani oleh pemerintah sangat luas. Dalam Teori Hukum Administrasi, rumus yang biasa digunakan dalam menentukan batasan fungsi pemerintahan adalah menggunakan teknik residu. Fungsi atau urusan pemerintahan adalah fungsi yang tersisa di luar kekuasaan legislatif dan yudisial. ${ }^{2}$ Kekuasaan legislatif adalah kekuasaan untuk membentuk undang-undang; sedangkan kekuasaan yudisial adalah kekuasaan untuk melakukan ajudikasi, yaitu memeriksa, mengadili dan memutus perkara berdasarkan hukum. Mengingat keluasan fungsi atau urusan pemerintahan maka menjadi wajar adanya jika pemerintah diberikan keleluasaan dalam menentukan pilihan terkait dengan banyaknya instrumen tindak pemerintahan yang disediakan, salah satunya adalah kontrak. Adanya bermacam-macam pilihan instrumen tindak pemerintahan (bestuur handelingen) dimaksudkan untuk digunakan dalam rangka mewujudkan tujuan negara yang lebih besar.

Istilah kontrak (dengan) pemerintah merupakan terjemahan harafiah untuk istilah government contract, yaitu kontrak yang pihaknya adalah pemerintah, baik antar badan pemerintah maupun antara pemerintah dengan pihak swasta. ${ }^{3}$ Secara umum kontrak memiliki pengertian: "a juridical act, established - in compliance with possible formalities, required by the law - by the corresponding and mutually interdependent expressions of intent of two or more parties, directed at the creation of juridical effects for the benefit of one of the parties and to the account of the other party, or for the benefit and to the account of both parties." 4

Unsur perbedaan kontrak secara umum dengan kontrak pemerintah ada pada keterlibatan unsur pemerintah di dalamnya. Sebagai implikasinya, berlaku beberapa kekhususan pengaturan secara hukum dengan mengingat bahwa ada pemerintah sebagai pihak dalam kontrak tersebut. ${ }^{5}$ Itu berarti, asas dan ketentuan

\footnotetext{
2 Philipus M. Hadjon et.al., Pengantar Hukum Administrasi Indonesia, Gadjah Mada University Press, Yogyakarta, 2002, hlm. 3-4.

3 Peter Cane, Administrative Law, Oxford University Press, Oxford, 2011, hlm. 224.

4 Arthur S. Hartkamp dan Marianne M.M. Tillema, Contract Law in the Netherlands, Kluwer Law International, The Hague, 1995, hlm. 33.

5 Bandingkan dengan Ralph C. Nash, Jr., "The Government Contract Decisions of the Federal Circuit", The George Washington University Law Review, Volume 78, Nomor 3, 2010, hlm. 614.
} 
hukum yang bersifat umum mengenai kontrak tetap berlaku dengan pengecualian karena ada kondisi khusus tersebut di mana ada pemerintah yang berkontrak. Pengertian ini sejalan dengan pandangan Mariam Darus Badrulzaman yang menggunakan konsep perjanjian publik untuk konsep kontrak pemerintah. Badrulzaman menyatakan: "Perjanjian publik adalah perjanjian yang diadakan dengan badan hukum publik. Misalnya, negara, provinsi, mengadakan perjanjian jual beli, sewa-menyewa. Perjanjian ini mempunyai sifat hukum publik karena pada perjanjian ini salah satu pihaknya adalah negara."6

Pendapat Badrulzaman diamini dan dipertajam oleh Yohanes Sogar Simamora, dengan menyatakan: "Sebagai konsekuensi pemanfaatan instrumen Hukum Perdata oleh pemerintah, khususnya Hukum Kontrak, dalam pengelolaan urusan pemerintahan yang lazim disebut sebagai kontraktualisasi (contractualization), terjadi percampuran antara elemen privat dan publik dalam hubungan kontraktual yang terbentuk. Kontrak yang dibuat oleh pemerintah karenanya mempunyai karakteristik yang berbeda dengan kontrak privat pada umumnya. Implikasi adanya percampuran elemen privat dan publik itu tidak saja mengenai keabsahan dalam pembentukan kontrak, tetapi juga pada aspek pelaksanaan serta penegakan hukumnya (enforcement of the contract). Adanya unsur hukum publik inilah yang menyebabkan aturan dan prinsip hukum dalam kontrak privat tidak sepenuhnya berlaku bagi kontrak yang dibuat oleh pemerintah."7

Tindak pemerintahan yang dilakukan oleh pemerintah secara kontraktual pada hakikatnya mengurangi potensi penggunaan kekuasaan atau kewenangan pemerintahan secara unilateral atau sepihak berdasarkan konsepsi tindakan pemerintah sebagai penguasa. Hal ini merupakan implikasi dari sifat konsensual kontrak. ${ }^{8}$ Kontraktualisasi urusan pemerintahan, yaitu penggunaan instrumen kontrak dalam menyelenggarakan urusan pemerintahan, pada hakikatnya sekadar merupakan pilihan cara yang bersifat pragmatis. Logikanya, jika hal itu mampu mempermudah kerja pemerintah, mengapa penggunaan instrumen kontrak

\footnotetext{
6 Mariam Darus Badrulzaman, Hukum Perikatan dalam KUH Perdata Buku Ketiga: Yurisprudensi, Doktrin serta Penjelasan, PT. Citra Aditya Bakti, Bandung, 2015, hlm. 94.

7 Yohanes Sogar Simamora, Hukum Perjanjian: Prinsip Hukum Kontrak Pengadaan Barang dan Jasa oleh Pemerintah, LaksBang PRESSindo, Yogyakarta, 2010, hlm. 54.

8 Randy E. Barnett, Consenting to Form Contracts, Fordham Law Review, Volume 71, Nomor 3, 2002, hlm. 634-635.
} 
tersebut tidak dilakukan? Pertimbangan pragmatis demikian merupakan daya dorong proses kontraktualisasi urusan pemerintahan di mana tidak perlu semua urusan pemerintahan dikerjakan sendiri oleh pemerintah demi alasan efisiensi (seperti pertimbangan keahlian yang kebetulan tidak dimiliki oleh pemerintah). ${ }^{9}$

Indroharto mengemukakan beberapa alasan positif terkait dengan penggunaan instrumen keperdataan dalam penyelenggaraan urusan pemerintahan sebagai berikut:

a. warga negara telah terbiasa berkecimpung dalam suasana kehidupan Hukum Perdata;

b. lembaga keperdataan telah terbukti kemanfaatannya dan sudah dikenal sebagai bentuk yang digunakan dalam perundang-undangan yang luas dan yurisprudensi;

c. lembaga keperdataan dapat diterapkan hampir untuk segala keperluan karena sifatnya yang fleksibel dan jelas sebagai suatu instrumen;

d. lembaga keperdataan dapat diterapkan karena terdapat kebebasan bagi para pihak dalam membuat perjanjian;

e. seringkali terjadi jalur hukum publik menemui jalan buntu, tetapi jalur melalui Hukum Perdata justru dapat memberikan jalan keluarnya;

f. ketegangan yang disebabkan oleh tindakan yang selalu bersifat sepihak dari pemerintah dapat dikurangi; dan

g. berbeda dengan tindakan yang bersifat sepihak dari pemerintah, tindakan menurut Hukum Perdata dapat memberikan jaminan-jaminan kebendaan, misalnya ganti rugi. ${ }^{10}$

Pada hakikatnya, asas dan ketentuan hukum tentang kontrak pemerintah memiliki kekhususan jika dibandingkan dengan asas dan ketentuan hukum tentang kontrak secara umum. Dalam kontrak pemerintah, selain memiliki dimensi hukum privat, juga ada dimensi hukum publik. Walau asas atau prinsip umumnya menyatakan bahwa dengan pendekatan kontraktualisasi pemerintah memilih untuk menundukkan diri pada hukum privat, namun kedudukan pemerintah sebagai penguasa tidak pernah berubah dengan adanya kondisi yuridis tersebut.

${ }^{9}$ Paul R. Verkuil, Outsourcing Sovereignty, Cambridge University Press, Cambridge, 2007, hlm. 188. Lihat juga: Paul R. Verkuil, Is Efficient Government an Oxymoron?, Duke Law Journal, Volume 43, Nomor 6, 1994, hlm. 1221-1222; Jon D. Michaels, Privatization's Pretensions, The University of Chicago Law Review, Volume 77, Nomor 2, 2010, hlm. 717-719; Jonathan Levin dan Steven Tadelis, Contracting for Government Services: Theory and Evidence from U.S. Cities, The Journal of Industrial Economics, Volume LVIII, Nomor 3, 2010, hlm. 535.

10 Sebagaimana dikutip dalam Yohanes Sogar Simamora, Op.Cit., hlm. 79-80. Lihat juga Lalu Hadi Adha, Kontrak Build Operate Transfer sebagai Perjanjian Kebijakan Pemerintah dengan Pihak Swasta, Jurnal Dinamika Hukum, Volume 11, Nomor 3, 2011, hlm. 554. 
Pemerintah sebagai penguasa memiliki keistimewaan-keistimewaan berdasarkan hukum, salah satunya adalah memiliki kekuasaan mengatur. Kendati dengan jalan kontraktualisasi pemerintah menyepakati pengaturan dirinya dengan pihak lawan berkontraknya (yang lazim disebut dengan tindakan privat atau keperdataan), namun hal ini tidak mutlak karena kesepakatan yang menghasilkan kontrak atau perjanjian tersebut tetap dapat menjadi objek pengaturan oleh pemerintah. ${ }^{11}$

Dalam kalimat lebih teoretis, kontrak pemerintah condong kurang akomodatif terhadap asas atau prinsip kebebasan berkontrak dibandingkan dengan kontrak secara umum. Dengan demikian, tingkat intervensi oleh peraturan perundang-undangan relatif lebih tinggi. Situasi ini perlu pemakluman karena menyangkut urusan pemerintahan, pengaturan tersebut adalah bentuk perlindungan terhadap keistimewaan pemerintah yang tidak dapat dikesampingkan begitu saja oleh mekanisme konsensualitas, terutama terkait dengan posisi pemerintah sebagai penyelenggara kepentingan umum. ${ }^{12}$

Ketentuan umum yang relevan dalam konteks kontrak pemerintah adalah Pasal $1320 \mathrm{KUH}$ Perdata tentang syarat sahnya kontrak atau perjanjian yaitu: kesepakatan, kecakapan, hal tertentu dan sebab yang halal (kausa halal). Rasio keberlakuan Pasal 1320 KUH Perdata tersebut adalah karena ketentuan tersebut merupakan aturan umum yang menentukan keabsahan bagi semua jenis kontrak dan sekaligus merupakan implikasi dari tindak pemerintahan yang dilakukan oleh pemerintah sebagai civil actor yang melakukan perbuatan hukum keperdataan.13 Dalam teori, dua unsur pertama disebut syarat subjektif (kesepakatan dan kecakapan); sementara dua unsur terakhir disebut syarat objektif (hal tertentu dan sebab yang halal). ${ }^{14}$ Pembedaan tersebut berkaitan dengan isu kebatalan suatu kontrak atau perjanjian. Badrulzaman menyatakan: "Apabila cacat itu mengenai syarat subjektif, perjanjian itu dapat dibatalkan (vernietigbaar) dan selama

\footnotetext{
11 Bandingkan dengan Yohanes Sogar Simamora, Ibid., hlm. 84-85.

12 Dalam Teori Hukum Publik dikonstruksikan bahwa negara menyandang identitas rangkap sebagai penguasa yang berdaulat (jure imperii) dan sebagai orang perorangan biasa (jure gestionis) yang masing-masing tindakan dalam identitas tersebut memiliki implikasi berbeda. Markus Krajewski dan Christopher Singer, Should Judges be Front-Runners? The ICJ, State Immunity and the Protection of Fundamental Human Rights, Max Planck Yearbook of United Nations Law, Volume 16, 2012, hlm. 17-18.

13 Yohanes Sogar Simamora, Op. Cit., hlm. 91.

${ }^{14}$ Mariam Darus Badrulzaman, Op. Cit., hlm. 107.
} 
pembatalannya belum diajukan, perjanjian itu sah. Jika cacat itu ada pada syarat objektif, perjanjian itu batal demi hukum (van rechtswege nietig, null and void)."15

Pada sisi pemerintah maka isu hukum penting dalam kaitan dengan kontrak pemerintah adalah tentang wewenang, substansi dan prosedur dalam melakukan tindakan "berkontrak" dengan pihak swasta. Dengan pengertian lain, tiga isu hukum tersebut merupakan kerangka analisis yang bersifat baku dalam melakukan penilaian atas keabsahan hukum suatu tindak pemerintahan.

Perihal wewenang, hal prinsipilnya adalah suatu tindak pemerintahan hanya dapat dilakukan atas dasar kewenangan pemerintahan. Wewenang merupakan dasar bertindak bagi pemerintah. Untuk itu ada tiga cara perolehan wewenang secara yuridis. Pertama, dengan cara atribusi (attribution): "power is granted to an administrative authority by an independent legislative body. The power is initial (originair), which is to say that it is not derrived from a previously existing power. The legislative body creates independent and previously non-existent powers and assigns them to an authority." 16

Kedua, dengan cara delegasi (delegation): "the transfer of an acquired attribution of power from one administrative authority to another, so that the delegatee (the body that has acquired the power) can exercise power in its own name." 17 Perbedaan antara atribusi dan delegasi adalah: "an already existing power is being transferred."18 Prinsipnya, delegasi harus dilakukan sesuai asas legalitas: "delegation of an original power is only possible under the condition that the legal regulation in which the power rests, provides for the possibility of delegation."19 Sementara sebagai implikasi dari delegasi: "If the originally empowered body (the delegator) decides on a transfer, then that body can no longer exercise the power itself; only the delegatee is empowered to exercise it." 20

Cara terakhir dalam perolehan wewenang adalah mandat (mandate): "With mandate, there is no transfer, but the mandate-giver (mandans) assigns power to the other

${ }^{15}$ Ibid., hlm. 108. hlm. 16.

${ }^{16}$ J.G. Brouwer \& A.E. Schilder, A Survey of Dutch Administrative Law, Ars Aequi Libri, Nijmegen, 1998,

${ }^{17}$ Ibid., hlm. 17.

${ }^{18}$ Ibid.

${ }^{19}$ Ibid.

${ }^{20}$ Ibid. 
body (mandataris) to make decisions or take action in its name." ${ }^{21}$ Lebih lanjut, tentang karakteristiknya: "the mandans retains its power and that decisions made by the mandans." 22 Mengingat dalam mandat tidak terjadi proses peralihan atau pelimpahan wewenang, maka sebagai implikasinya, berbeda dengan delegasi: "Because the mandans remains formally responsible, it is indispensable that it be able to intervene at need ... the mandans can give general and specific instructions as how the power must be exercised ... the body given the mandate must provide requested information ... the mandate can be terminated at any time." 23 Kaidah umum yang berlaku dalam mandat adalah: "the mandate construction is possible under the condition that the legal regulation that the power is based on does not prohibit it and that the nature of the authority is not in opposition to it." 24

Isu tentang wewenang sangat relevan dengan ketentuan tentang syarat kecakapan dalam Pasal 1320 KUH Perdata yang merupakan salah satu indikator keabsahan suatu perjanjian berdasarkan unsur subjektif. Kecakapan di sini adalah tentang kapasitas atau kemampuan untuk berkontrak (capacity to contract) yang dari sisi Hukum Administrasi hal itu dikonsepsikan dengan konsep khusus yaitu sebagai wewenang. Dengan pengertian lain, syarat kapasitas atau kemampuan berkontrak yang dimaksudkan oleh Pasal 1320 KUH Perdata memiliki pengertian khusus dalam konteks kontrak pemerintah karena hal itu merujuk pada konsep Hukum Administrasi yang disebut wewenang. ${ }^{25}$ Itu artinya, pihak yang mewakili pemerintah (bertindak untuk dan atas nama pemerintah) dalam kontrak tersebut harus relevan dengan wewenang pemerintahan yang menentukan bahwa pihak yang bersangkutan memiliki kapasitas untuk melakukan tindak pemerintahan, dalam hal ini mewakili pemerintah untuk mengikatkan diri ke dalam kontrak.

Dalam kaitan dengan obyek kontrak berupa tukar menukar BMD berupa tanah, maka ketentuan umum tentang perjanjian tukar menukar juga berlaku. Pertama, konsep yuridis (legal concept) dari perjanjian tukar menukar dalam Pasal

${ }^{21}$ Ibid., hlm. 18.

22 Ibid.

23 Ibid., hlm. 19.

${ }^{24}$ Ibid., hlm. 18.

25 Mohammad Sahlan, "Unsur Menyalahgunakan Kewenangan dalam Tindak Pidana Korupsi sebagai Kompetensi Absolut Peradilan Administrasi”, Jurnal Hukum Ius Quia Iustum, Volume 23, Nomor 2, 2016, hlm. 275 276. 
1541 KUH Perdata menentukan: “Tukar menukar ialah suatu persetujuan dengan mana kedua belah pihak mengikatkan diri untuk saling memberikan suatu barang secara timbal balik sebagai ganti suatu barang lain." Kedua, objek dari perjanjian tukar menukar yaitu dalam Pasal 1542 KUH Perdata yaitu: “Segala sesuatu yang dapat dijual, dapat pula jadi pokok persetujuan tukar-menukar." Ketiga, untuk selebihnya, hal-hal yang relevan secara yuridis adalah dikembalikan posisinya sebagai suatu kontrak atau perjanjian di mana aspek-aspek regulatif tentang kontrak atau perjanjian, sepanjang yang merupakan ketentuan hukum yang bersifat memaksa, tidak fakultatif, maka ketentuan-ketentuan itu memiliki keberlakuan.

Terakhir adalah tentang prosedur. Dalam tindak pemerintahan, prosedur memiliki makna sangat penting untuk diperhatikan oleh pemerintah ketika melakukan tindak pemerintahan. Cacat prosedur dapat berpengaruh terhadap keabsahan tindak pemerintahan meskipun tidak terlampau bersifat substansial. Jika tidak ada hambatan yang bersifat substansial, cacat prosedur dapat dikoreksi dengan melakukan pengulangan tindak pemerintahan tersebut yang dilakukan dengan jalan lebih memperhatikan ketentuan prosedural yang diberlakukan $a$ priori. Salah satu contoh isu prosedural penting di lingkungan Hukum Administrasi modern adalah partisipasi atau peran serta masyarakat sebagai bentuk kepatuhan Hukum Administrasi terhadap asas demokrasi. ${ }^{26}$

\section{Landasan Peraturan Perundang-Undangan Terkait dengan Tukar Menukar BMD}

Telaah normatif berkenaan dengan perjanjian tukar menukar BMD memumpun pada 3 hal yaitu: wewenang, substansi, dan prosedur. Dalam Pasal 1 angka 2 PP No. 27 Tahun 2014 juncto Pasal 1 angka 16 Permendagri No. 19 Tahun 2016 ditegaskan tentang pengertian BMD yaitu semua barang yang dibeli atau diperoleh atas beban Anggaran Pendapatan dan Belanja Daerah atau berasal dari perolehan lainnya yang sah. Lebih lanjut ditegaskan bahwa Pengelolaan BMD meliputi: perencanaan kebutuhan dan penganggaran; pengadaan; penggunaan;

\footnotetext{
${ }^{26}$ Bandingkan dengan Philipus M. Hadjon et.al., Op.Cit., hlm. 28-29. Lihat juga Cheryl Simrell King, Kathryn M. Feltey dan Bridget O’Neill Susel," The Question of Participation: Toward Authentic Public Participation in Public Administration", Public Administration Review, Volume 58, Nomor 4, 1998, hlm. 318-319.
} 
pemanfaatan; pengamanan dan pemeliharaan; penilaian; pemindahtanganan; pemusnahan; penghapusan; penatausahaan; dan pembinaan, pengawasan dan pengendalian.

Pemindahtanganan BMD dilakukan dengan cara: penjualan, tukar menukar, hibah, atau penyertaan modal Pemerintah Pusat/Daerah. Tukar Menukar adalah pengalihan kepemilikan BMD yang dilakukan antara Pemerintah Pusat dengan Pemerintah Daerah, antar Pemerintah Daerah, atau antara Pemerintah Pusat/Pemerintah Daerah dengan pihak lain, dengan menerima penggantian utama dalam bentuk barang, paling sedikit dengan nilai seimbang.

Pengaturan tentang kewenangan pengelolaan BMD diatur dalam PP No. 27 Tahun 2014 dan Permendagri No. 19 Tahun 2016. Dalam Pasal 1 angka 5 juncto Pasal 9 Permendagri No. 19 Tahun 2016, Kepala Daerah adalah pejabat yang memegang kekuasaan pengelolaan BMD, yang berwenang dan bertanggung jawab: a. menetapkan kebijakan pengelolaan BMD; b. menetapkan penggunaan, pemanfaatan, atau pemindahtanganan BMD berupa tanah dan/atau bangunan; $\mathrm{c}$. menetapkan kebijakan pengamanan dan pemeliharaan BMD; d. menetapkan pejabat yang mengurus dan menyimpan BMD; e. mengajukan usul pemindahtanganan BMD yang memerlukan persetujuan DPRD; $f$. menyetujui usul pemindahtanganan, pemusnahan, dan penghapusan BMD sesuai batas kewenangannya; g. menyetujui usul pemanfaatan BMD berupa sebagian tanah dan/atau bangunan dan selain tanah dan/atau bangunan; dan $h$. menyetujui usul pemanfaatan BMD dalam bentuk Kerja Sama Penyediaan Infrastruktur.

Selanjutnya dalam Pasal 10 Permendagri a quo diatur bahwa Sekretaris Daerah adalah Pengelola BMD yang berwenang dan bertanggung jawab:

a. meneliti dan menyetujui rencana kebutuhan BMD;

b. meneliti dan menyetujui rencana kebutuhan pemeliharaan/perawatan BMD;

c. mengajukan usul pemanfaatan dan pemindahtanganan BMD yang memerlukan persetujuan Gubernur/Bupati/Walikota;

d. mengatur pelaksanaan penggunaan, pemanfaatan, pemusnahan, dan penghapusan $\mathrm{BMD}$;

e. mengatur pelaksanaan pemindahtanganan BMD yang telah disetujui oleh Gubernur/Bupati/Walikota atau DPRD;

f. melakukan koordinasi dalam pelaksanaan inventarisasi BMD;

g. melakukan pengawasan dan pengendalian atas pengelolaan BMD. 
Kemudian dalam Pasal 8 PP No. 27 Tahun 2014 disebutkan bahwa Kepala Satuan Kerja Perangkat Daerah adalah Pengguna BMD, yang berwenang dan bertanggung jawab:

a. mengajukan rencana kebutuhan dan penganggaran BMD bagi satuan kerja perangkat daerah yang dipimpinnya;

b. mengajukan permohonan penetapan status penggunaan BMD yang diperoleh dari beban APBD dan perolehan lainnya yang sah;

c. melakukan pencatatan dan inventarisasi BMD yang berada dalam penguasaannya;

d. menggunakan BMD yang berada dalam penguasaannya untuk kepentingan penyelenggaraan tugas dan fungsi satuan kerja perangkat daerah yang dipimpinnya;

e. mengamankan dan memelihara BMD yang berada dalam penguasaannya;

f. mengajukan usul pemanfaatan dan pemindahtanganan BMD berupa tanah dan/atau bangunan yang tidak memerlukan persetujuan DPRD dan BMD selain tanah dan/atau bangunan;

g. menyerahkan BMD berupa tanah dan/atau bangunan yang tidak digunakan untuk kepentingan penyelenggaraan tugas dan fungsi satuan kerja perangkat daerah yang dipimpinnya dan sedang tidak dimanfaatkan Pihak Lain, kepada Gubernur/ Bupati/Walikota melalui Pengelola Barang;

h. mengajukan usul pemusnahan dan penghapusan BMD;

i. melakukan pembinaan, pengawasan, dan pengendalian atas penggunaan BMD yang berada dalam penguasaannya; dan

j. menyusun dan menyampaikan laporan barang pengguna semesteran dan laporan barang pengguna tahunan yang berada dalam penguasaannya kepada Pengelola Barang.

Selanjutnya terkait substansi, dalam Pasal 307 UU No. 23 Tahun 2014 diatur tentang pengelolaan BMD sebagai berikut: (i) BMD yang diperlukan untuk penyelenggaraan urusan pemerintahan tidak dapat dipindahtangankan; (ii) BMD yang tidak digunakan untuk penyelenggaraan urusan pemerintahan dapat dihapus dari daftar BMD dengan cara dijual, dipertukarkan, dihibahkan, disertakan sebagai modal daerah, dan/atau dimusnahkan sesuai dengan ketentuan peraturan perundang-undangan. Kemungkinan untuk memindahtangankan BMD yang tidak diperlukan bagi penyelenggaraan tugas pemerintahan daerah juga diatur dalam Pasal 329 ayat (1) Permendagri No. 19 Tahun 2016.

Pemindahtanganan BMD berupa tukar menukar (Pasal 64 PP No. 27 Tahun 2014 jo Pasal 377 ayat 1 Permendagri No. 19 Tahun 2016) dilaksanakan dengan pertimbangan: a. untuk memenuhi kebutuhan operasional penyelenggaraan 
pemerintahan; b. untuk optimalisasi Barang Milik Negara/Daerah; dan c. tidak tersedia dana dalam Anggaran Pendapatan dan Belanja Negara/Daerah.

Selain pertimbangan sebagaimana disebutkan di atas, berdasarkan Pasal 377 ayat (3) Permendagri No. 19 Tahun 2016, tukar menukar dapat dilakukan dengan pertimbangan:

a. apabila BMD berupa tanah dan/atau bangunan sudah tidak sesuai dengan tata ruang wilayah atau penataan kota;

b. guna menyatukan BMD yang lokasinya terpencar;

c. dalam rangka pelaksanaan rencana strategis pemerintah pusat/pemerintah daerah;

d. guna mendapatkan/memberikan akses jalan, apabila objek tukar menukar adalah BMD berupa tanah dan/atau bangunan; dan/atau

e. telah ketinggalan teknologi sesuai kebutuhan, kondisi, atau ketentuan peraturan perundang-undangan, apabila objek tukar menukar adalah BMD selain tanah dan/atau bangunan.

Kemudian, dalam Pasal 377 ayat (4) Permendagri a quo ditegaskab bahwa tukar menukar BMD dapat dilakukan dengan pihak: Pemerintah Pusat; Pemerintah Daerah lainnya; Badan Usaha Milik Negara/Daerah atau badan hukum milik pemerintah lainnya yang dimiliki negara; Pemerintah Desa; atau Swasta, baik yang berbentuk badan hukum maupun perorangan.

Sementara dalam Pasal 378 Permendagri No. 19 Tahun 2016 disebutkan tentang obyek tukar menukar BMD sebagai berikut:

(1)Tukar menukar BMD dapat berupa:

a. tanah dan/atau bangunan yang telah diserahkan kepada Gubernur/Bupati/Walikota;

b. tanah dan/atau bangunan yang berada pada Pengguna Barang;dan

c. selain tanah dan/atau bangunan.

(2)Tanah dan/atau bangunan yang berada pada Pengguna Barang sebagaimana dimaksud pada ayat (1) huruf $b$ antara lain tanah dan/atau bangunan yang masih dipergunakan untuk penyelenggaraan tugas dan fungsi Pengguna Barang, tetapi tidak sesuai dengan tata ruang wilayah atau penataan kota.

(3)Tukar menukar sebagaimana dimaksud pada ayat (1) dilaksanakan oleh Pengelola Barang.

Berkenaan dengan tukar menukar BMD, diatur pula barang pengganti (Pasal 381 Permendagri No. 19 Tahun 2016) yaitu berupa: barang sejenis dan/atau barang tidak sejenis. Barang pengganti utama tukar menukar BMD berupa tanah, harus berupa tanah atau tanah dan bangunan. Barang pengganti utama tukar menukar BMD berupa bangunan, dapat berupa: tanah; tanah dan bangunan; bangunan; 
dan/atau selain tanah dan/atau bangunan. Barang pengganti harus berada dalam kondisi siap digunakan pada tanggal penandatanganan perjanjian tukar menukar.

Nilai barang pengganti atas tukar menukar paling sedikit seimbang dengan nilai wajar BMD yang dilepas. Apabila nilai barang pengganti lebih kecil daripada nilai wajar BMD yang dilepas, mitra tukar menukar wajib menyetorkan ke rekening Kas Umum Daerah atas sejumlah selisih nilai antara nilai wajar BMD yang dilepas dengan nilai barang pengganti. Selanjutnya dalam Pasal 383 diatur bahwa apabila pelaksanaan tukar menukar mengharuskan mitra tukar menukar membangun bangunan barang pengganti, mitra tukar menukar menunjuk konsultan pengawas dengan persetujuan Gubernur/Bupati/Walikota berdasarkan pertimbangan dari SKPD terkait. Konsultan pengawas merupakan badan hukum yang bergerak di bidang pengawasan konstruksi. Biaya konsultan pengawas menjadi tanggung jawab mitra tukar menukar.

Terakhir, terkait prosedur, tukar menukar BMD dilaksanakan dengan tatacara yang diatur dalam Pasal 67 PP No. 27 Tahun 2014 maupun Permendagri No. 19 Tahun 2016. Dalam rangka pemindahtanganan BMD dilakukan penilaian untuk memperoleh nilai yang wajar. (Pasal 330). Tukar menukar dilaksanakan setelah dilakukan kajian berdasarkan (Pasal 379):

a. aspek teknis, antara lain: (i) kebutuhan Pengelola Barang/Pengguna Barang; dan (ii) spesifikasi barangyang dibutuhkan;

b. aspek ekonomis, antara lain kajian terhadap nilai barang milik daerahyang dilepas dan nilai barang pengganti;

c. aspek yuridis, antara lain: (i) tata ruang wilayah dan penataan kota; dan (ii) bukti kepemilikan.

Berdasarkan kajian terhadap BMD berupa tanah dan/atau bangunan, Gubernur/Bupati/Walikota dapat memberikan alternatif bentuk lain pengelolaan BMD atas permohonan persetujuan tukar menukar yang diusulkan oleh Pengelola Barang/Pengguna Barang (Pasal 380).

Adapun tata cara tukar menukar BMD pada Pengelola Barang sebagai berikut:

1. Pelaksanaan tukar menukar BMD dilakukan berdasarkan: (a) kebutuhan dari Pengelola Barang untuk melakukan tukar menukar; atau (b) permohonan tukar menukar dari pihak sebagaimana dimaksud dalam Pasal 377 ayat (4). 
2. Pelaksanaan tukar menukar BMD yang didasarkan pada kebutuhan pengelola barang, diawali dengan pembentukan Tim oleh Gubernur/Bupati/Walikota untuk melakukan penelitian mengenai kemungkinan melaksanakan tukar menukar. Penelitian meliputi: (a) penelitian kelayakan tukar menukar, baik dari aspek teknis, ekonomis, maupun yuridis; (b) penelitian data administratif; dan (c) penelitian fisik.

Penelitian administratif dilakukan untuk meneliti:

a. status penggunaan dan bukti kepemilikan, gambar situasi termasuk lokasi tanah, luas, peruntukan, kode barang, kode register, nama barang, dan nilai perolehan, untuk data barang milik daerah berupa tanah;

b. tahun pembuatan, kode barang, kode register, nama barang, konstruksi bangunan, luas, status kepemilikan, lokasi, nilai perolehan, dan nilaibuku, untuk data barang milik daerah berupa bangunan;

c. tahun perolehan, kode barang, kode register, nama barang, jumlah, nilai perolehan, nilai buku, kondisi barang, dan bukti kepemilikan kendaraan untuk data barang milik daerah berupa selain tanah dan/atau bangunan.

Penelitian fisik dilakukan dengan cara mencocokkan fisik barang milik daerah yang akan ditukarkan dengan data administratif.

3. Hasil penelitian dituangkan dalam berita acara penelitian. Tim menyampaikan berita acara hasil penelitian kepada Gubernur/Bupati/Walikota untuk penetapan BMD menjadi objek tukar menukar.

4. Berdasarkan penetapan tersebut, Pengelola Barang menyusun rincian rencana barang pengganti sebagai berikut: a. tanah meliputi luas dan lokasi yang peruntukannya sesuai dengan tata ruang wilayah; b. bangunan meliputi: jenis, luas, dan konstruksi bangunan serta sarana dan prasarana penunjang; c. selain tanah dan bangunan meliputi jumlah, jenis barang, kondisi barang dan spesifikasi barang. Pengelola Barang melakukan penilaian terhadap barang milik daerah yang akan ditukarkan dan barang pengganti. Hasil Penilaian disampaikan Pengelola Barang kepada Gubernur/Bupati/Walikota.

5. Berdasarkan hasil penilaian, Gubernur/Bupati/Walikota melakukan penetapan mitra tukar menukar. Gubernur/Bupati/Walikota menerbitkan keputusan tukar menukar paling sedikit memuat: mitra tukar menukar; BMD 
yang akan dilepas; nilai wajar BMD yang akan dilepas yang masih berlaku pada tanggal keputusan diterbitkan; dan rincian rencana barangpengganti.

6. Pengelola Barang mengajukan permohonan persetujuan tukar menukar kepada Gubernur/Bupati/Walikota. Dalam hal tukar menukar memerlukan persetujuan DPRD, Gubernur/Bupati/Walikota terlebih dahulu mengajukan permohonan persetujuan tukar menukar kepada DPRD.

7. Berdasarkan surat persetujuan tukar menukar, Gubernur/Bupati/Walikota dan mitra tukar menukar menandatangani perjanjian tukar menukar. Setelah menandatangani perjanjian tukar menukar, mitra tukar menukar melaksanakan: a. pekerjaan pembangunan/pengadaan barang pengganti sesuai dengan perjanjian tukar menukar, untuk tukar menukar atas barang milik daerahberupa tanah dan/atau bangunan; b. pekerjaan melaksanakan pekerjaan pengadaan barang pengganti sesuai dengan perjanjian tukar menukar termasuk menyelesaikan pengurusan dokumen administratif yang diperlukan, tukar menukar atas barang milik daerahberupa selain tanah dan/atau bangunan.

8. Gubernur/Bupati/Walikota membentuk Tim untuk melakukan monitoring pelaksanaan pengadaan/pembangunan barang pengganti berdasarkan laporan konsultan pengawas dan penelitian lapangan.

9. Sebelum dilakukan penyerahan BMD yang dilepas, Pengelola Barang melakukan penilaian terhadap kesesuaian barang pengganti sesuai dengan yang tertuang dalam perjanjian tukar menukar. Dalam hal hasil penilaian menunjukkan bahwa terdapat ketidaksesuian spesifikasi dan/atau jumlah barang pengganti dengan perjanjian tukar menukar, mitra tukar menukar berkewajiban melengkapi/memperbaiki ketidaksesuai tersebut. Dalam hal kewajiban mitra tukar menukar untuk melengkapi/memperbaiki tidak dapat dipenuhi, maka mitra tukar menukar berkewajiban untuk menyetorkan selisih nilai barang milik daerah dengan barang penggantike rekening Kas Umum Daerah. Gubenur/Bupati/Walikota membentuk Tim untuk melakukan penelitian kelengkapan dokumen barang pengganti, antara lain bukti 
kepemilikan, serta menyiapkan Berita Acara Serah Terima (BAST) untuk ditandatangani oleh Pengelola Barang dan mitra tukar menukar.

10. Berdasarkan perjanjian Tukar Menukar Pengelola Barang melakukan serah terima barang, yang dituangkan dalam BAST. Berdasarkan BAST, Pengelola Barang mengajukan usulan penghapusan barang milik daerah yang dilepas dari daftar barang Pengelola kepada Gubernur/Bupati/Walikota serta Pengelola Barang mencatat dan mengajukan permohonan penetapan status penggunaan terhadap barang pengganti sebagai barang milik daerah.

11. Pelaksanaan tukar menukar barang milik daerah yang didasarkan pada permohonan dari pihak sebagaimana dimaksud dalam Pasal 385 huruf b, diawali dengan mengajukan permohonan secara tertulis kepada Gubernur/Bupati/ Walikota. Permohonan sebagaimana dimaksud pada ayat (1) disertai data pendukung berupa: a. rincian peruntukan; b. jenis/spesifikasi; c. lokasi/data teknis; d. perkiraan nilai barang pengganti; dan e. hal lain yang diperlukan.

12. Pelaksanaan tukar menukar barang milik daerah yang didasarkan pada kebutuhan Pengelola Barang berlaku mutatis mutandis pada Pelaksanaan tukar menukarbarang milik daerah yang didasarkan pada permohonan dari pihak sebagaimana dimaksud dalam Pasal 377 ayat (4).

\section{Aspek Doelmatigheid Tukar Menukar BMD}

Asas umum dalam Hukum Administrasi menentukan bahwa keabsahan dalam arti luas atas suatu tindak pemerintahan tidak hanya ditentukan oleh aspek rechtmatigheid-nya, yaitu keterpenuhan standar hukum, tetapi juga ditentukan oleh pertimbangan berdasarkan aspek doelmatigheid-nya, atau kemanfaatannya. Menjelaskan konsep doelmatigheid, Philipus M. Hadjon menggunakan istilah sinonimnya dalam bahasa Indonesia yaitu "ketepatgunaan". ${ }^{27}$ Aspek doelmatigheid ini ditujukan pada situasi setelah tindakan dilakukan (ex nunc) yang berbeda dengan aspek rechtmatigheid yang ditujukan pada situasi pada saat tindakan dilakukan $\left(\right.$ ex tunc) ${ }^{28}$ 
Dalam pengertian demikian, aspek doelmatigheid berorientasi pada dampak (impact) yang dikehendaki setelah tindakan dilakukan. Oleh karena itu isu utama dari aspek doelmatigheid ialah pertimbangan dari segi kemanfaatan atau utilitas, yang mencakup dua aspek, yaitu efektivitas dan efisiensi. Aspek efektivitas merujuk pada kondisi ketercapaian tujuan atau sasaran. ${ }^{29}$ Sementara aspek efisiensi merujuk pada kondisi kehematan dalam proses mencapai tujuan (baca: minimalisasi penggunaan sumber daya dalam mencapai suatu tujuan). ${ }^{30}$ Pemikiran tentang efisiensi dan efektivitas tindak pemerintahan ini sejatinya sejalan dengan ajaran Economic Analysis of Law yang dipopulerkan oleh Richard Posner di mana badan-badan pemerintah diharapkan untuk membuat atau menghasilkan keputusan-keputusan "to maximize social wealth". ${ }^{31}$

Doelmatigheid tindak pemerintahan dalam perjanjian tukar menukar BMD (tanah) hendaknya dipahami dari posisi pemerintah sebagai penyelenggara pemerintahan yang bertindak mewakili negara yang berhadap-hadapan dengan rakyat (yang diperintah - the governed). Rakyat di sini, dalam negara, tersegmentasi dalam banyak kepentingan. Satu contoh klasik adalah buruh versus pengusaha; stockholder versus stakeholder. Rakyat di sini, dalam pengertian lebih spesifik adalah dunia usaha yang menanamkan modalnya untuk melakukan aktivitas bisnis, yaitu aktivitas yang bersifat mencari keuntungan ekonomi.

Setiap rakyat, dalam negara, memiliki kepentingan-kepentingan dan harapan-harapan sah (legitimate expectations) yang wajib dipenuhi oleh pemerintahnya. Oleh karena itu, setelah sebelumnya didiskusikan isu tentang rechtmatigheid tindak pemerintahan dalam kasus ini, maka selanjutnya yang akan didiskusikan adalah isu tentang doelmatigheid tindak pemerintahan tersebut dengan melihat posisi pemerintah vis-à-vis dunia usaha. Doelmatigheid ini tidak hanya dimaksudkan untuk menjawab doelmatig-nya tindak pemerintahan untuk dunia usaha (swasta), tetapi juga untuk menjawab doelmatig-nya tindak pemerintahan dalam hubungan dengan kepentingan masyarakat yang lebih luas.

\footnotetext{
${ }^{29}$ Efektivitas di sini adalah "the extent to which a defined goal is attained using specific means." Klaus Mathis, Efficiency Instead of Justice: Searching for the Philosophical Foundations of the Economic Analysis, Springer, Dordrecht, 2009, hlm. 190. ${ }^{30}$ Efisiensi di sini lebih mengarah pada faktor produktivitas. Ibid.

${ }^{31}$ Ronald Dworkin, "Why Efficiency? A Response to Professors Calabresi and Posner", Hofstra Law Review, Volume 8, Nomor 3, 1980, hlm. 573.
} 
Kerangka berpikir yang seyogianya digunakan adalah fungsi pemerintah visà-vis rakyat dalam arti luas. Pemerintah tidak hanya memiliki fungsi regulatif atau mengatur, tetapi juga memiliki fungsi fasilitatif atau memberikan kemudahankemudahan (fasilitas) kepada rakyatnya. ${ }^{32}$ Sebagai implikasinya, tindak pemerintahan, dalam hal ini melalui perjanjian tukar menukar BMD (tanah), memiliki relevansi dengan fungsi fasilitatif pemerintah, yang pada analisis akhir harus dinilai atau diuji berdasarkan kesesuaiannya dengan pencapaian tujuan pemerintahan secara umum supaya terpenuhi aspek doelmatigheid dari tindak pemerintahan tersebut.

Sebagaimana dijelaskan sebelumnya, menilai apakah suatu tindakan doelmatig atau tidak pada hakikatnya bersifat ex post karena isu utama penilaian doelmatigheid lebih ditujukan pada situasi setelah tindakan dilakukan atau ex nunc. Namun demikian, apakah suatu tindak pemerintahan akan mampu memenuhi aspek doelmatigheid-nya atau tidak juga bukan sesuatu yang mustahil untuk dapat diproyeksikan secara ex ante. Proyeksi yang bersifat prediktif cukup dimungkinkan, setidaknya untuk menghindari kemungkinan suatu tindak pemerintahan menyimpang terlampau jauh dari aspek doelmatigheid-nya. Satu contoh, di bidang pembentukan peraturan perundang-undangan, hal demikian sudah menjadi praktik yang cukup lazim, seperti metode regulatory impact assessment, sebelum suatu peraturan perundang-undangan diberlakukan. Di Swiss, misalnya, untuk pengujian tersebut diberlakukan standar: “(1) necessity and possibility of State action; (2) impacts on individual social groups; (3) impacts on the whole economy; (4) alternative regulations; (5) expediency in enforcement." 33 Dalam pengertian demikian, mutatis mutandis, rumus tersebut juga dapat diberlakukan saat Pemerintah hendak melakukan perjanjian tukar-menukar BMD (tanah).

Oleh karena itu, doelmatigheid dari tindak pemerintahan pada hakikatnya (harus) dapat diprediksi dan sekaligus diantisipasi sejak sebelum tindak pemerintahan itu dilakukan. Itu artinya, tindak pemerintahan a quo dapat dirancang secara a priori supaya memenuhi tuntutan doelmatigheid-nya. Dalam

${ }^{32}$ Bandingkan dengan Yoram Barzel, A Theory of the State: Economic Rights, Legal Rights and the Scope of the State, Cambridge University Press, Cambridge, 2002, hlm. 1. Gagasan tentang fungsi negara yang dipertahankan Barzel adalah perlindungan terhadap kebutuhan-kebutuhan individu dan, kemudian, kelompok.

${ }_{33}$ Klaus Mathis, Op. Cit., hlm. 205. 
konteks demikian, parameter atau kriteria yang relevan perlu diletakkan lebih dahulu sebelum pada akhirnya diberikan judgment bahwa tindak pemerintahan $a$ quo mampu doelmatig.

Tindak pemerintahan dalam kaitan dengan perjanjian tukar-menukar BMD (tanah) pada hakikatnya adalah bersifat fasilitasi terhadap dunia usaha dalam pemanfaatan tanah yang berada di bawah penguasaan pemerintah untuk ditukar dengan tanah yang mereka miliki. Analisis doelmatigheid di sini tentunya berpijak pada pemahaman a priori bahwa secara rechtmatigheid tidak ada persoalan manakala mengikuti kaidah peraturan perundang-undangan yang berlaku.

Berpijak pada upaya tukar-menukar BMD ini maka semangat terkait dengan fasilitasi oleh pemerintah tersebut perlu dikaitkan dengan kebijakan pemerintahan dalam skala lebih makro dalam rangka menciptakan iklim berusaha yang kondusif dan produktif. Kebijakan makro tersebut pada hakikatnya bersifat self-evident sebagai kondisi niscaya yang berlaku di semua negara dalam rangka menciptakan, dan menjaga, pertumbuhan ekonomi yang mampu berkontribusi positif dalam rangka penciptaan kesejahteraan umum dalam suatu negara. Dikaitkan dengan sasaran ini maka tindak pemerintahan dalam kasus ini, dapat diperkirakan, memenuhi kriteria doelmatig karena akan sejalan dengan sasaran dari kebijakan makro pemerintah tersebut di mana fasilitasi terhadap kegiatan investasi sangat relevan dengan upaya menciptakan pertumbuhan ekonomi dan memajukan kesejahteraan umum.

Jika dari sisi kebijakan pemerintahan makro tindak pemerintahan tersebut doelmatig maka pertanyaan selanjutnya adalah adakah dampak negatifnya? Dampak negatif tersebut dalam pengertian lebih operasional ialah apakah kepentingan masyarakat luas kemudian menjadi terganggu oleh adanya tindak pemerintahan a quo? Supaya tindak pemerintah tidak berdampak negatif terhadap kepentingan masyarakat luas maka hal itu dapat diantisipasi dengan prosedur partisipasi masyarakat. Partisipasi masyarakat telah diakui sebagai metode yang relevan dalam rangka menjamin efektivitas dan efisiensi tindak pemerintahan. Pelibatan masyarakat sebagai pihak terdampak, baik langsung maupun tidak langsung, suatu tindak pemerintahan dirasa efektif dalam mencegah supaya 
kepentingan masyarakat luas tidak dirugikan oleh suatu tindak pemerintahan. Oleh karena itu, sebagai bagian dari isu prosedural, partisipasi masyarakat ini perlu didorong untuk doelmatigheid suatu tindak pemerintahan, seperti pada kasus ini, terutama untuk menghindari inefektivitas dan inefisiensi tindak pemerintahan.

\section{Penutup}

Beranjak dari uraian sebelumnya, dapat disimpulkan beberapa hal sebagai berikut. Pertama, secara teoretis, pemerintah (pemerintah daerah) pada asas/prinsipnya dapat melakukan kontraktualisasi urusan pemerintahan, dan hal ini sudah menjadi praktik yang biasa (kebiasaan) di lingkungan pemerintahan. Sesuai dengan lingkup isu atau permasalahan hukum yang dihadapi, kontraktualisasi tersebut termasuk untuk melakukan perjanjian tukar menukar dengan pihak non-pemerintah dengan melibatkan aset (tanah) yang berada di bawah penguasaan pemerintah (BMD).

Kedua, secara yuridis, perjanjian tukar menukar sebagai alas hak untuk peralihan aset (tanah) yang berada di bawah penguasaan pemerintah (BMD) dapat ditemukan dasar pengaturannya dalam peraturan perundang-undangan sehingga memberikan sinyal bahwa tindakan tersebut tidak dilarang (atau ada kemungkinan untuk dilakukan). Dalam melakukan tindakan tersebut berlaku syarat dan ketentuan peraturan perundang-undangan sebagai dasar keabsahan dari tindakan tersebut yang meliputi aspek: kewenangan, substansi dan prosedur. Hal prinsipnya adalah, dalam tukar menukar tersebut, berlaku perlindungan terhadap kekayaan negara (daerah) di mana negara (daerah) tidak boleh dirugikan melalui tindakan tukar menukar. Terakhir, ketiga, di samping aspek pemenuhan atau kepatuhan terhadap peraturan perundang-undangan (rechtmatigheid), hal yang juga menjadi penentu kelayakan tindakan pemerintah dalam melakukan perjanjian tukar-menukar BMD (berupa tanah) yaitu aspek kemanfaatan (doelmatigheid).

\section{Daftar Pustaka}

\section{Buku}

Badrulzaman, Mariam Darus, Hukum Perikatan dalam KUH Perdata Buku Ketiga: Yurisprudensi, Doktrin serta Penjelasan, PT. Citra Aditya Bakti, Bandung, 2015. 
Barzel, Yoram, A Theory of the State: Economic Rights, Legal Rights and the Scope of the State, Cambridge University Press, Cambridge, 2002.

Brouwer, J.G. \& A.E. Schilder, A Survey of Dutch Administrative Law (Ars Aequi Libri, Nijmegen), 1998.

Cane, Peter, Administrative Law, Oxford University Press, Oxford, 2011.

Hadjon, Philipus M., Perlindungan Hukum bagi Rakyat di Indonesia, Penerbit Bina Ilmu, Surabaya, 1987.

Hadjon, Philipus M., et.al., Pengantar Hukum Administrasi Indonesia, Gadjah Mada University Press, Yogyakarta, 2002.

Hartkamp, Arthur S., dan Marianne M.M. Tillema, Contract Law in the Netherlands, Kluwer Law International, The Hague, 1995.

Mathis, Klaus, Efficiency Instead of Justice: Searching for the Philosophical Foundations of the Economic Analysis, Springer, Dordrecht, 2009.

Simamora, Yohanes Sogar, Hukum Perjanjian: Prinsip Hukum Kontrak Pengadaan Barang dan Jasa oleh Pemerintah, LaksBang PRESSindo, Yogyakarta, 2010.

Verkuil, Paul R., Outsourcing Sovereignty, Cambridge University Press, Cambridge, 2007.

\section{Jurnal}

Adha, Lalu Hadi, “Kontrak Build Operate Transfer sebagai Perjanjian Kebijakan Pemerintah dengan Pihak Swasta", Jurnal Dinamika Hukum, Volume 11, Nomor 3, 2011.

Barnett, Randy E., "Consenting to Form Contracts”, Fordham Law Review, Volume 71, Nomor 3, 2002.

Dworkin, Ronald, "Why Efficiency? A Response to Professors Calabresi and Posner, Hofstra Law Review", Volume 8, Nomor 3, 1980.

King, Cheryl Simrell, Kathryn M. Feltey dan Bridget O’Neill Susel, “The Question of Participation: Toward Authentic Public Participation in Public Administration", Public Administration Review, Volume 58, Nomor 4, 1998.

Krajewski, Markus, dan Christopher Singer, "Should Judges be Front-Runners? The ICJ, State Immunity and the Protection of Fundamental Human Rights", Max Planck Yearbook of United Nations Law, Volume 16, 2012.

Levin, Jonathan, dan Steven Tadelis, "Contracting for Government Services: Theory and Evidence from U.S. Cities", The Journal of Industrial Economics, Volume LVIII, Nomor 3, 2010.

Michaels, Jon D., "Privatization's Pretensions”, The University of Chicago Law Review, Volume 77, Nomor 2, 2010.

Nash, Jr., Ralph C., "The Government Contract Decisions of the Federal Circuit", The George Washington University Law Review, Volume 78, Nomor 3, 2010. 
Sahlan, Mohammad, Unsur Menyalahgunakan Kewenangan dalam Tindak Pidana Korupsi sebagai Kompetensi Absolut Peradilan Administrasi, Jurnal Hukum Ius Quia Iustum, Volume 23, Nomor 2, 2016.

Santoso, Urip, Perjanjian Bangun Guna Serah antara Pemerintah Kabupaten/Kota dan Perseroan Terbatas, Mimbar Hukum, Volume 24, Nomor 1, 2014.

Verkuil, Paul R., Is Efficient Government an Oxymoron?, Duke Law Journal, Volume 43, Nomor 6, 1994.

\section{Peraturan Perundang-undangan:}

UU No. 23 Tahun 2014 tentang Pemerintahan Daerah (Lembaran Negara Republik Indonesia Tahun 2014 Nomor 244; Tambahan Lembaran Negara Republik Indonesia Nomor 5587), sebagaimana telah diubah, terakhir dengan Undang Undang Nomor 9 Tahun 2015 (Lembaran Negara Republik Indonesia Tahun 2015 Nomor 58; Tambahan Lembaran Negara Republik Indonesia Nomor 5679).

PP No. 27 Tahun 2014 tentang Pengelolaan Barang Milik Negara/Daerah (Lembaran Negara Republik Indonesia Tahun 2014 Nomor 92; Tambahan Lembaran Negara Republik Indonesia Nomor 5533).

Permendagri No. 19 Tahun 2016 tentang Pedoman Pengelolaan Barang Milik Daerah (Berita Negara Republik Indonesia Tahun 2016 Nomor 547). 